\title{
Natural Cytotoxicity Triggering Receptor 3
}

National Cancer Institute

\section{Source}

National Cancer Institute. Natural Cytotoxicity Triggering Receptor 3. NCI Thesaurus. Code C104550.

Natural cytotoxicity triggering receptor 3 (201 aa, $22 \mathrm{kDa}$ ) is encoded by the human NCR3 gene. This protein plays a role in natural killer cell function. 